\title{
Research Square \\ Comparison between Heat Pipes based condenser and Conventional condenser of Power Plant
}

Mallikharjuna Rao Tarla ( $\square$ malliktarla@gmail.com )

Central Power Research Institute https://orcid.org/0000-0002-1992-2246

\section{Research Article}

Keywords: Exergy, heat transfer coefficient Power Plant, Steam Condenser, Wickless heat pipe

Posted Date: February 19th, 2021

DOI: https://doi.org/10.21203/rs.3.rs-172887/v1

License: (c) (i) This work is licensed under a Creative Commons Attribution 4.0 International License. Read Full License 


\title{
Comparison between Heat Pipes based condenser and Conventional condenser of Power Plant
}

\author{
T Mallikharjuna Rao ${ }^{1}$
}

${ }^{1}$ Central Power Research Institute, Bangalore ,India,

Keywords: : Exergy; heat transfer coefficient Power Plant, Steam Condenser; Wickless heat pipe.

Correspondence to: T Mallikharjuna Rao / malliktarla@gmail.com

Abstract This paper explores the feasibility of using heat pipes for steam condensation and heat pipe based condenser. The concept of heat pipes for steam condensation is newly proposed and studied herewith. . CFD analysis and Experimental studies carried on the single heat pipe for steam condensation. Experimental setup and results of heat pipes based steam condenser presented. Properties like Effectiveness, heat transfer surface area, exergy analysis for the conventional condenser made of simple copper tubes and heat pipe based condenser are compared

\section{INTRODUCTION}

Improving the energy efficiency and miniaturization are continual processes in industrial world and power sector has no exception. At present, the major of dependence for electric power is on thermal power generation. Nevertheless, as compared to other industrial sectors, especially electronic industry the miniaturization of major subcomponents of thermal power station is minimal. Reports on improvement in thermodynamic energy efficiency and exergy efficiency among thermal power generation components like boiler, turbine ,condenser etc. are very little. In this work, the design modification of condenser has been proposed and also the advantages of the proposed condenser has been compared with the conventional condenser. The proposal of condenser modification is presented with the help of a case study which is described below.

\section{Case Study}

A $210 \mathrm{MW}$ thermal power plant operating in India was considered. This plant is a base load plant, operates on Rankine cycle with reheating. The plant is equipped with different sub components like Boiler (consisting of pulverized coal firing burners, super heater, re heater, economizer etc.), 3 stage Steam turbine (High pressure turbine, Intermediate Pressure Turbine, Low Pressure Turbine ) , Condenser etc. Feed water is pumped by Boiler feed pump into the boiler and the boiler converts this water into super-heated steam and streams this super-heated steam into the turbine. The steam exhaust of the turbine will be dumped into condenser. Condenser converts this steam into water which again fed into the boiler as feed water.

Condenser converts the steam into water with help of cooling water flowing through the condenser tubes. During this process, the heat energy from the steam transfers from the steam to cooling water due to which there will be temperature rise in the cooling water. This visible temperature rise indicates that, the heat transfer mechanism, employed for the purpose condensing the steam is single phase mechanism. Because of this single phase mechanism a large heat transfer area is required to handle the steam exited from the turbine resulting large number of condenser tubes.

This paper describes the technology for improvement of efficiency and the miniaturization of this condenser by improving the heat transfer mechanism. It is proposed a two phase heat transfer mechanism in condenser which enhances the heat transfer capability and improves the effectiveness of condenser. The introduction of this two phase heat transfer mechanism is achieved by using heat pipes in place of conventional condenser tubes.

3. Description of Heat Pipe Heat pipe is a man-made heat transfer device which transports large quantities of heat with minimum temperature gradient without any additional power between the two temperatures limits [1]. It consists of three different sections namely evaporator, adiabatic and condenser and a working fluid inside the heat pipe. The heat energy to be transferred will be 
streamed on the evaporator section of heat pipe. The working fluid present in the heat pipes will absorb the heat energy and converts into vapour (change of phase). This vapour will migrate from the hotter portion of heat pipe to the cooler section of heat pipe which is condenser portion of the heat pipe. In this section vapour condenses back to liquid by releasing absorbed heat energy to the cooling media present at peripheral area of condenser section of the heat pipe. The condensed heat pipe liquid drops back to vapour section by gravitational force or through wick. Due, to the latent heat of evaporation of working fluid inside heat pipe, considerable quantities of heat energy will be transported by this heat pipe. The evaporator and condenser sections of a heat pipe function independently, needing only common liquid. Amir Faghri [2] reported in his text book the details of heat pipe and also wide applications of heat pipes. These heat pipes were utilized to upgrade the design of the condenser in thermal power plants.

\section{3.a Literature Review on the Application of heat pipes}

In 1981, Littwin and McCurely [3] reported that usage of HPHE (Heat exchanger made by heat pipes) for steam generation and for preheating of combustion air in fossil fuel fired power plants. Vasiliev et al (1984) [4] described the usage of HPHE for waste heat recovery systems. Hong Zhang, Jun Zhuang [5] in 2003 narrated the application of heat pipes for different industrial uages. L.L Vasiliev in 2005 [6] described the application of Heat pipes in modern heat exchangers and indicated the use of heat pipes in thermal power plants.

But, the heat transfer Industries have not explored the condensation of steam using the heat pipes or heat pipe based condenser., in spite of excellent heat transfer capabilities of heat pipes. This paper address the usage of heat pipe for steam condensation and also heat pipe based condenser.

\subsection{CONCEPT OF THE PROPOSED HEAT PIPE BASED CONDENSER}

The mechanism of steam condensation using heat pipe is presented in the Fig. 2. The steam incidents on the heat pipe evaporator surface at $46{ }^{\circ} \mathrm{C}$. The evaporator will be heaving the water (as working fluid inside the heat pipe) at a pressure of 0.07 bar. At this pressure the boiling temperature of the water is $39.02{ }^{\circ} \mathrm{C}$. Therefore the $\Delta T$ will be (4639.02) $6.98^{\circ} \mathrm{C}$. For 0.07 bar, $\Delta T_{\text {chf }}$ is equal to 14 ${ }^{\circ} \mathrm{C}$, which is greater than $\Delta T$ in the present case. Hence nucleate boiling will occur.

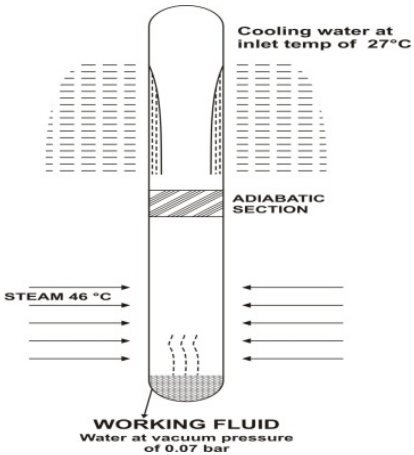

Fig 2. Proposed concept steam condensation

So the vapors from the evaporator regions enters the condenser portion of heat pipe. This portion is maintained at a surface temperature of $27^{\circ} \mathrm{C}$ with the help of inlet cooling water. So, the vapors which reached the top portion of the heat pipe will condense on side surface of the heat pipe by releasing heat gained at evaporator section to the cooling water. The condensate will flow down due to gravity. The cycle repeats as the process go on.

\section{4.a CFD Analysis of the proposed heat Pipe}

Computational fluid dynamic analysis is carried out to know the working of the fluid inside heat pipe. For the analysis, exact boundary conditions similar to experimental set up are applied for CFD analysis. The analysis is carried out on a single heat pipe as shown in Fig 3.
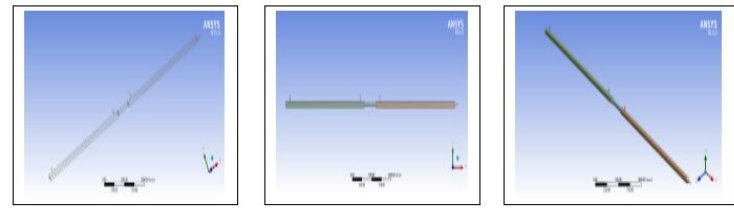

Fig 3.0 The Heat pipes under analysis.

The CFD glimpses of the heat pipe under analysis are shown in Fig 4. And CFD results are shown in Table 1.
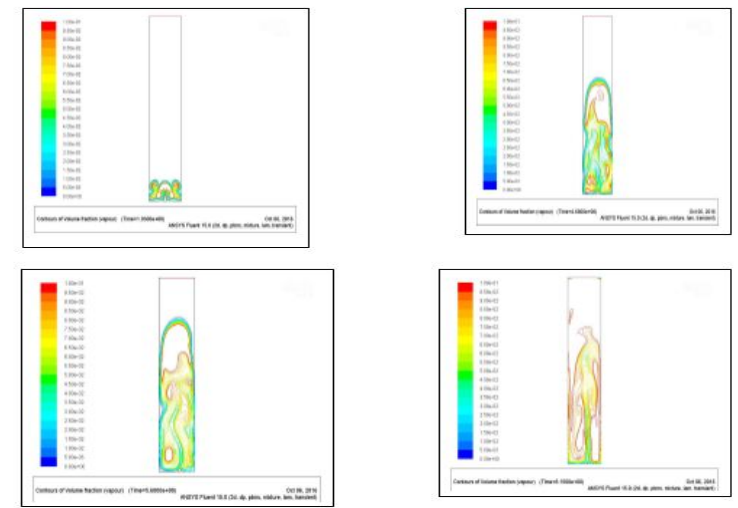

Fig 4. Heat pipe liquid changes inside heat pipe 
Tabel 1 : CFD REsults

\begin{tabular}{l|l|l|l}
$\begin{array}{l}\text { Steam } \\
\text { in let } \\
\text { Pres- } \\
\text { sure in } \\
\text { abso- } \\
\text { lute bar }\end{array}$ & $\begin{array}{l}\text { Steam In } \\
\text { let temper- } \\
\text { ature }\end{array}$ & $\begin{array}{l}\text { Conden- } \\
\text { sate tem- } \\
\text { perature }\end{array}$ & $\begin{array}{l}\text { Cold water outh } \\
\text { perature }\end{array}$ \\
\hline 0.080 & $318.5 \mathrm{~K}$ & $317.7 \mathrm{~K}$ & 308.4 \\
\hline 0.090 & $317.8 \mathrm{~K}$ & $315.3 \mathrm{~K}$ & $307.4 \mathrm{~K}$ \\
\hline 0.10 & $318.8 \mathrm{~K}$ & $317.5 \mathrm{~K}$ & $308.3 \mathrm{~K}$
\end{tabular}

From the above it can be concluded steam Condensate temp is around $46^{\circ} \mathrm{C}$ and considering the input conditions,

The out let heat energy calculated is $36258.63 \mathrm{w}$ But the $h_{f g}$ for this temperature and pressure is $2392.1 \times 10^{3} \mathrm{w} / \mathrm{kg}$

So, the quantity of Condensate $=36258.63 / 239100$

$=0.015157 \mathrm{~kg} / \mathrm{hr}$

$$
=0.909 \mathrm{lit} / \mathrm{min}
$$

The above designed heat pipe is experimented in the following case study.

\subsection{Case Study}

The details of Condenser chosen for this case study are presented in Table 2.

Table 2. Details of condenser

\begin{tabular}{|c|c|}
\hline Parameter & Type/Numerical value \\
\hline $\begin{array}{l}\text { Plant } \\
\text { Unit Load }\end{array}$ & $\begin{array}{l}\text { Coal based thermal power } \\
\text { plant ,210 MW (191 MW dur- } \\
\text { ing the time of considera- } \\
\text { tion) }\end{array}$ \\
\hline Condenser type & Surface type, single pass \\
\hline $\begin{array}{lr}\text { Steam inlet } & \text { tem- } \\
\text { perature } & \text { and } \\
\text { pressure } & \\
\end{array}$ & $46^{\circ} \mathrm{C} \& 0.09$ bar \\
\hline $\begin{array}{lr}\text { Inlet } & \text { and } \text { out } \\
\text { cooling } & \text { water } \\
\text { Temp } & \\
\end{array}$ & $26.62^{\circ} \mathrm{C} \& 37.26^{\circ} \mathrm{C}$ \\
\hline $\begin{array}{l}\text { Total Condenser } \\
\text { Tubes }\end{array}$ & 19,208, Copper material \\
\hline $\begin{array}{l}\text { Copper Tube OD } \\
\& \text { ID }\end{array}$ & $25.4 \& 24.0 \mathrm{~mm}$ \\
\hline $\begin{array}{l}\text { Copper } \\
\text { Length }\end{array}$ & $11.28 \mathrm{~m}$ \\
\hline Heat load & $\begin{array}{l}221171743.8 \mathrm{Kcal} / \mathrm{hr}, 260 \\
\mathrm{MW}\end{array}$ \\
\hline Water Flow & $21033.95 \mathrm{t} / \mathrm{hr}, 5842.76 \mathrm{~kg} / \mathrm{s}$ \\
\hline $\begin{array}{l}\text { Load on Each con- } \\
\text { denser tube and } \\
\text { heat transfer rate } \\
\text { per unit area }\end{array}$ & $13.5 \mathrm{~kW}$ and $15 \mathrm{~kW} / \mathrm{m}^{2}$ \\
\hline
\end{tabular}

A suitable heat pipe is designed to suit the requireletremband its specifications are presented in Table 3. The thermodynamics details of the designed heat pipe are presented in the Table 4.

Table 3. Details of Proposed HeatPipe

\begin{tabular}{l|l}
\multicolumn{1}{c|}{ Parameter } & \multicolumn{1}{|c}{ Numerical value } \\
\hline Heat Pipe length & $4.3 \mathrm{~m}$ \\
\hline Heat Pipe material & Copper \\
Heat Pipe vacuum & 0.07 bar \\
\hline Fluid inside heat pipe & Distilled water \\
\hline $\begin{array}{l}\text { Saturation temperature } \\
\text { of fluid }\end{array}$ & $39.02^{\circ} \mathrm{C}$ \\
\hline Wick material & Wickless heat pipe
\end{tabular}

A condenser using the above designed heat pipe is proposed. The details of the proposed condenser using the specially designed heat pipes are presented in Table 4.

Table -4. Proposed Condenser

\begin{tabular}{l|l}
\multicolumn{1}{c|}{ Parameter } & \multicolumn{1}{c}{ Value } \\
\hline Total heat pipes & 9025 \\
\hline $\begin{array}{l}\text { Arrangement of Heat } \\
\text { pipes in HPHPE }\end{array}$ & Staggered, 95 x 95 \\
\hline $\begin{array}{l}\text { Load on each Heat Pipe } \\
\text { and heat transfer rate per } \\
\text { unit area }\end{array}$ & $\begin{array}{l}28.8 \mathrm{~kW} \approx 30 \mathrm{~kW} \\
\text { and } 84.73 \mathrm{~kW} / \mathrm{m}^{2}\end{array}$ \\
\end{tabular}

Tabe 5. Thermodynamic properties of designed heat pipe

\begin{tabular}{l|l|l} 
Parameters & $\begin{array}{c}\text { Desired re- } \\
\text { quirements } \\
\text { of Heat } \\
\text { Pipes in the } \\
\text { proposed } \\
\text { HPHE }\end{array}$ & $\begin{array}{c}\text { Designed } \\
\text { Heat pipes } \\
\text { characteris- } \\
\text { tics }\end{array}$ \\
\hline $\begin{array}{l}\text { Maximum heat } \\
\text { transfer limit } \\
\text { from the Boiling } \\
\text { point of view }\end{array}$ & $30 \mathrm{~kW}$ & $71 \mathrm{~kW} *$ \\
\hline $\begin{array}{l}\text { Maximum heat } \\
\text { transfer limit } \\
\text { from the Flood- } \\
\text { ing point of } \\
\text { view }\end{array}$ & $30 \mathrm{~kW}$ & $59.3 \mathrm{~kW} *$ \\
\hline $\begin{array}{l}\text { Overall heat } \\
\text { transfer coeffi- } \\
\text { cient under pre- } \\
\text { vailing condi- } \\
\text { tions }\end{array}$ & & $2447 *$
\end{tabular}

( ${ }^{*}$ The detailed calculations are in Ref 7 by same author ) 
6.0 Comparison between conventional condenser and HPHE condenser.

Performance of the two types of condensers are calculated and presented below.

\section{6.a Effectiveness Comparison}

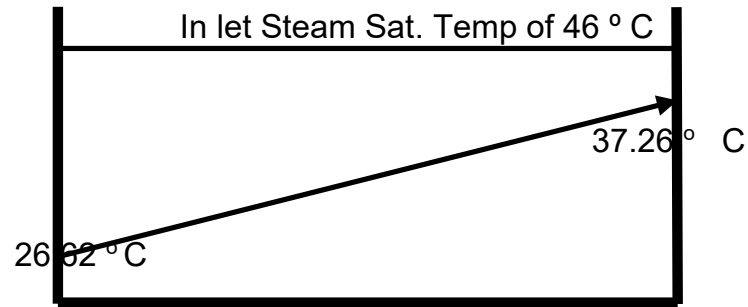

Fig 5 . Temperatures in the Condenser (Conventional Condenser)

Total Steam Load on the condenser $=Q=260,000$ $\mathrm{kW}$

Cooling Water Quantity $=5843 \mathrm{Kg} / \mathrm{s}$

\section{Conventional Condenser}

Total Steam Load on the condenser $=\mathrm{Q}=$ 260,000 kW

Cooling Water Quantity $=5843 \mathrm{Kg} / \mathrm{s}$

Actual Heat Transfer to the cooling water $=\mathrm{m} \mathrm{c}_{\mathrm{p}}$ ( $\left.T_{\text {cl,out }}-T_{c l, \text { in }}\right)$

$\mathrm{kW}$

$$
=5843 \times 4.178 \times(37.26-26.62)=259744.25
$$

Maximum possible heat transfer to the cooling water $=5843 \times 4.178 \times(46-26.62)=473105.60 \mathrm{~kW}$

Effectiveness of the Existing Condenser $=$ Actual Heat Transfer/Max. Possible Heat Transfer $=259744.25 / 473105.60$

$=0.549$ approximately $55 \%$

PROPOSED HEAT PIPE BASED CONDENSER

As per Faghri (Ref 2),the heat pipe condenser can be considered as liquid-coupled, indirect-transfertype exchanger system. The analysis procedure adopted from the [9] as liquid-coupled, indirecttransfer-type exchanger .

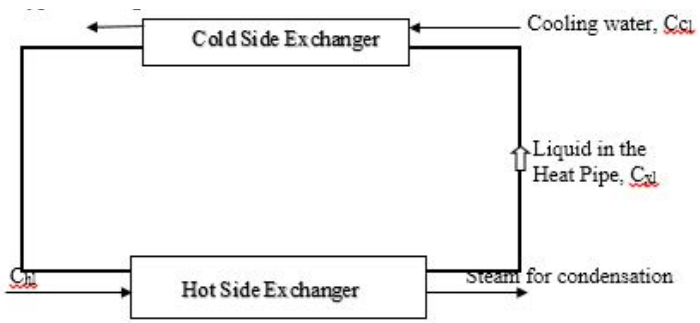

Fig 6. Equivalence between HP condenser and liquid coupled indirect Heat Exchanger

$\mathrm{C}=$ mass flow $\mathrm{x}$ specific heat $=$ Flow Stream capacity, kcal/s.K, Subscripts $\mathrm{xl}, \mathrm{cl}, \mathrm{hl}$ are coupling fluid, cold fluid, hot fluid respectively.

$\mathrm{C}_{\mathrm{p}}$ is specific heat of the fluid in $\mathrm{kcal} / \mathrm{kg} . \mathrm{K}$
$\mathrm{C}_{\mathrm{cl}}=$ Mass of cooling water $\mathrm{x} \mathrm{C}_{\mathrm{p}, \mathrm{c}}=(5843 / 9025) \mathrm{x}$ $4.187=2.71 \mathrm{~kJ} / \mathrm{s} . \mathrm{K}$

(Assuming cooling water distributed equally to all heat pipes)

$\mathrm{C}_{\mathrm{xl}}=\mathrm{m}_{\mathrm{xl}} \mathrm{x}_{\mathrm{p}, \mathrm{xl}}=$ mass of water used inside the heat pipe for the purpose

$$
=0.0125 \times 4.178=
$$

$0.0522 \quad \mathrm{~kJ} / \mathrm{s} . \mathrm{K}$

$\mathrm{C}_{\mathrm{hl}}=\mathrm{m}_{\mathrm{hl}} \times \mathrm{c}_{\mathrm{p}, \mathrm{hl}}=$ mass of steam condensed on each heat pipe $x$ specific heat of steam

$0.023 \mathrm{~kJ} / \mathrm{s} . \mathrm{K}$

$$
=0.012 \times 1.895=
$$

Now , Evaporator section of Heat pipe, $\mathrm{NTU}_{\mathrm{e}}=\mathrm{U}_{\mathrm{e}} \mathrm{T}$ $\mathrm{DL} \mathrm{e}_{\mathrm{e}} / \mathrm{m}_{\mathrm{e}} \mathrm{C}_{\mathrm{p}}$, \{ Adapted from E.Azd , F. Bahar et al, Design of Water-to -air Gravity assisted Heat Pipe Heat Exchanger, Peragon Press, 1985.\}

Now for evaporator section, NTUe $=\frac{U e A e}{m c p}$

Where $h_{e}=$ total thermal conductance of evaporator section $(\mathrm{W} / \mathrm{K})$

$\operatorname{tion}\left(\mathrm{m}^{2}\right)$

$A_{e}=$ outer area of evaporator sec-

$$
\mathrm{m} \quad=\text { mass flow rate of steam }(\mathrm{Kg} / \mathrm{s})
$$

Thermal resistance of evaporator section $=$ resistance due to steam entering+

resistance due to wall+ resistance inside heat pipe

$\mathrm{Re}=\mathrm{Ro}, \mathrm{e}+\mathrm{Rw}, \mathrm{e}+\mathrm{Ri}, \mathrm{e}$

$\mathrm{h}_{1}=$ heat transfer coefficient at outside of evaporator section of heat pipe

$\mathrm{h}_{2}=$ heat transfer coefficient at inside side of evaporator section of heat pipe

$\mathrm{h}_{3}=$ heat transfer coefficient at inside of condenser section of heat pipe

$\mathrm{h}_{4}=$ heat transfer coefficient at outside of condenser section of heat pipe

$$
\text { Ro,e }=\left(1 / h_{1} \quad x \text { Ao,e }\right)=(1 / 31543 \times 0.34)=
$$
$9.32 \times 10^{-5} \mathrm{~K} / \mathrm{W}$

$R w, e=\{\ln ($ do/di $) / 2 \pi k L\}=\{\ln (0.04540 / 0.0497) /$ $2 \pi k L\}=1.67 \times 10^{-5} \mathrm{~K} / \mathrm{W}$

$$
\begin{aligned}
& \mathrm{Ri}, \mathrm{e}=\left(1 / \mathrm{h}_{2} \times \mathrm{Ai}, \mathrm{e}\right)=(1 / 15521 \times 0.312)= \\
& 2.0 \times 10^{-5} \mathrm{~K} / \mathrm{W} \\
& \operatorname{Re}=9.32 \times 10^{-5}+1.67 \times 10^{-5}+2.0 \times \\
& 10^{-5}=1.3 \times 10^{-4} \mathrm{~K} / \mathrm{W} \\
& \mathrm{h} e=(1 / \operatorname{Re})=7698.2 \mathrm{~W} / \mathrm{K}
\end{aligned}
$$

NTUe $=\left(7698.2 \times 0.34 / 0.012 \times 1.895 \times 10^{3}\right)=$ 115.10 
Effectiveness of evaporator section is $\varepsilon_{\mathrm{e}}=1-\mathrm{e}$ NTUe $=1-e^{-115.10}=1$

\section{For condenser section}

Thermal resistance of condenser section $=$ resistance due to steam entering+

Resistance due to wall+ resistance inside heat pipe

$R c=R o, c+R w, c+R i, c$

Ro,c $=\left(1 / h_{4} \times A o, c\right)=(1 / 21405 \times 0.34)=1.59 \times$ $10^{-5} \mathrm{~K} / \mathrm{W}$

$\mathrm{Rw}, \mathrm{c}=\{\ln (\mathrm{do} / \mathrm{di}) / 2 \pi \mathrm{kL}\}=1.67 \times 10^{-5} \mathrm{~K} / \mathrm{W}$

$\mathrm{Ri}, \mathrm{c}=\left(1 / \mathrm{h}_{3} \times \mathrm{Ai}, \mathrm{c}\right)=(1 / 14065 \times 0.312)=2.21 \times 10^{-5}$ $\mathrm{K} / \mathrm{W}$

$R c=1.59 \times 10^{-5}+1.67 \times 10^{-5}+2.21 \times 10^{-5}=$ $5.47 \times 10^{-5} \mathrm{~K} / \mathrm{W}$

The heat transfer coefficients $\left(h_{1}\right.$ to $h_{4}$ are calculated as per the procedure adopted in Ref [7] published by same author)

$\mathrm{hc}=$ total thermal conductance of condenser section $(\mathrm{W} / \mathrm{K})$

$\mathrm{hc}=(1 / \mathrm{Rc})=18,281.5(\mathrm{~W} / \mathrm{K})$

NTUc $=\left(2570.7 \times 0.34 \quad / 0.65 \times 4.187 \times 10^{3}\right)=2.3$

Effectiveness of condenser section is $\varepsilon_{\mathrm{c}}=1-\mathrm{e}^{-}$ NTUC $=1-\mathrm{e}^{-2.3}=0.89$

For a heat pipe heat exchanger with $n$ rows of heat pipes (Ref 8),

For evaporator section, with $\mathrm{n}$ number of rows of heat pipes,

The net effectiveness, $\sum \varepsilon_{\mathrm{e}}=1-\left(1-\varepsilon_{\mathrm{e}}\right)^{\mathrm{n}}$

For condenser section, with $\mathrm{n}$ number of rows of heat pipes,

The net effectiveness $\sum \varepsilon_{c}=1-\left(1-\varepsilon_{c}\right)^{n}$

The overall effectiveness of the heat exchanger $\varepsilon_{0}$ is given by, Ref[9] $\varepsilon_{o}=\left\{1 / \sum \varepsilon_{e}+\left(C_{h l} / C_{c l}\right) \times\left(1 / \sum \varepsilon_{c}-1\right)\right\}^{-1} \quad$, since $\mathrm{C}_{\mathrm{cl}}>\mathrm{CXX}_{\mathrm{P}}>\mathrm{C}_{\mathrm{hl}}$

Appling numerical, $\varepsilon 0 \approx 0.99$

Hence it can be concluded that Heat pipe based condenser is more effective than conventional condenser.

\section{6.b Heat Transfer per unit area}

The Table 6 clearly brings out the comparison of heat transfer area of the conventional and heat pipe based condenser. $260 \mathrm{MW}$

Heat transfer Load on the condenser $=$

\begin{tabular}{l|l|l}
\multicolumn{1}{c}{ Parameter } & $\begin{array}{c}\text { Table 6 } \\
\text { Conventional } \\
\text { Condenser }\end{array}$ & $\begin{array}{c}\text { Heat Pipe } \\
\text { Based Con- } \\
\text { denser }\end{array}$ \\
\hline $\begin{array}{l}\text { Number of } \\
\text { Tubes }\end{array}$ & 19208 & $\begin{array}{l}9025 \text { Heat } \\
\text { pipes }\end{array}$ \\
\hline $\begin{array}{l}\text { Diameter of } \\
\text { tubes }\end{array}$ & $0.0254 \mathrm{~m}$ & $0.0540 \mathrm{~m}$ \\
\hline $\begin{array}{l}\text { Length of tubes } \\
\text { exposed for } \\
\text { steam conden- } \\
\text { sation }\end{array}$ & $11.28 \mathrm{~m}$ & $2 \mathrm{~m}$ \\
\hline $\begin{array}{l}\text { Total Heat } \\
\text { Transfer area } \\
\text { (Length } x \text { Perim- } \\
\text { eter } x \text { Number of } \\
\text { Tubes ) }\end{array}$ & $17289.2 \mathrm{~m}^{2}$ & $3062.1 \mathrm{~m}^{2}$ \\
\hline $\begin{array}{l}\text { Heat Transfer } \\
\text { Rate }\end{array}$ & $15 \mathrm{~kW} / \mathrm{m}^{2}$ & $85 \mathrm{~kW} / \mathrm{m}^{2}$ \\
\hline
\end{tabular}

6. c. EXERGY ANALYSIS

For Conventional Condenser $\exists=$ Destruction in Exergy $=T_{\text {env }}[\mathrm{CW}$ In

$\left.\left(T_{c l, o u t} / T_{c l, i n}\right)+C W\left(T_{c l, i n}-T_{c l, o u t}\right) / T_{s, i n}\right] \quad[10]$

Now, $\mathrm{CW}=$ Cooling water quantity $=5843 \mathrm{~kg} / \mathrm{s}$ ${ }^{\circ} \mathrm{C}=301 \mathrm{~K}$

$$
\mathrm{T}_{\text {env }}=\text { Temp. Of the Environment }=28
$$

$\mathrm{T}_{\mathrm{cl}, \text { out }}=$ Cooling water out let Temp $=$ $37.62{ }^{\circ} \mathrm{C}=310.62 \mathrm{~K}$

$\mathrm{T}_{\mathrm{cl}, \mathrm{in}}=$ Cooling water inlet Temp $=26.62$ ${ }^{\circ} \mathrm{C}=299.62 \mathrm{~K}$ $=319 \mathrm{~K}$

$$
\mathrm{T}_{\mathrm{s}, \mathrm{in}}=\text { Steam inlet temperature }=46^{\circ} \mathrm{C}
$$

Applying numerical,

Hence, $\quad \exists=301 \times 5843 \times 4.18 \times[\ln$ $(310.62 / 299.62+(299.62-310.62 / 319)]$ 
$(0.0361-0.0345)$

$$
\begin{aligned}
& =303 \times 5843 \times 4.18 \mathrm{x} \\
& =11,761 \mathrm{~kW}
\end{aligned}
$$

\section{For HPHE Condenser}

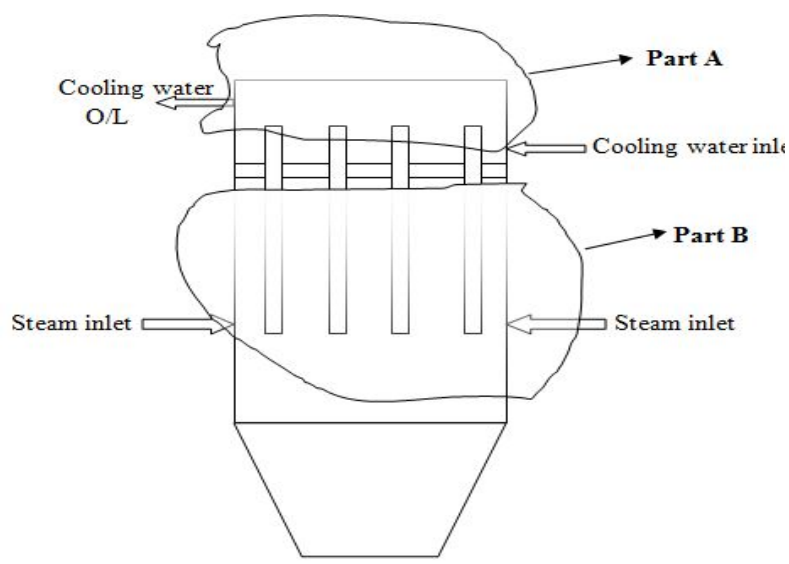

Analysis

Fig 7. Exergy

\section{For Part B}

Where steam condenses into water and fluid inside the heat pipe evaporates.

$$
\exists=h_{\text {ov }} A_{\text {ov }}(\pi T-1)^{2} / \pi \mathrm{T} \text { ] [10] }
$$

$\mathrm{h}_{\mathrm{ov}}=$ Overall heat transfer coefficient $=2406$

$\mathrm{W} / \mathrm{m}^{2} . \mathrm{K}$

$A_{\circ}=$ Overall heat transfer area $=1.3 \mathrm{~m}^{2}$

$\Pi_{\mathrm{T}} \quad=$ the ratio of input thermodynamic tempera-

ture of the streams $=46 / 39.02=1.179$

Applying numerical,

$$
\text { Hence, } \exists \quad=2406 \times 1.3 \times(1.179-1)^{2} \quad /
$$$$
1.179=85 \mathrm{~W}
$$

\section{For Part A}

Where cooling water gets heated and vapor inside heat pipe condenses into liquid.

$\exists=T_{\text {env }}\left[\mathrm{C}_{1} \ln \left(\mathrm{T}_{\mathrm{cl}, \text { out }} / \mathrm{T}_{\mathrm{cl}, \text { in }}\right)+\mathrm{C}_{1}\left(\mathrm{~T}_{\mathrm{cl}, \mathrm{in}-}\right.\right.$

$\mathrm{C}_{\mathrm{c}}=$ Heat capacity of water stream, $\mathrm{W} / \mathrm{k}$

$\mathrm{T}_{\mathrm{cl}, \mathrm{i}}=$ temperature in $\mathrm{K}$ of cooling water at inlet $=$ 299.62

$\mathrm{T}_{\mathrm{cl}, \mathrm{out}}=$ temperature in $\mathrm{K}$ of cooling water at outlet $=310.26$

$\mathrm{T}_{2}^{\prime}=$ temperature in $\mathrm{K}$ of vapor inside heat pipe before condensation. $=312.02$

Hence,$\exists=301 \times 5843 \times 4.178 \times[\mathrm{In}$ $(310.26 / 299.62)+(299.62-$ $310.26) / 312.02]$

$$
=7348028.3 \mathrm{x}
$$

$$
=5878.4 \mathrm{~kW}
$$

Total Exergy destruction in Part $\mathrm{A}$ and Part $\mathrm{B}=$ $5878 \mathrm{~kW}+85 \mathrm{~kW}=5963.4 \approx$ $5963 \mathrm{~kW}$

Hence it can be concluded that Heat pipe based condenser is more suitable than conventional condenser from the point of view of Exergy.

\subsection{EXPERIMENTAL SET UP AND FABRICATION PROCESS}

The heat pipe lower portion is enclosed with a jacket in which steam is injected for condensation purposes. Top portion is enclosed with another jacket which acts like a cooling water jacket. The portion of heat pipe enclosed for steam condensation acts as evaporator of the heat pipe and the portion which is enclosed by cold water jacket as condenser of the heat pipe. The inlet and out let temperatures are measured with the digital thermometers implanted at the inlet and outlet openings. Steam with different temperatures is allowed to enter steam jacket from opening and this steam is condensed and condensate is exited from tap provided. Cold water allowed to enter the cold water jacket bottom opening and allowed to exit from the top opening.

Experiments were carried out on single heat pipe as shown in Fig 8.0
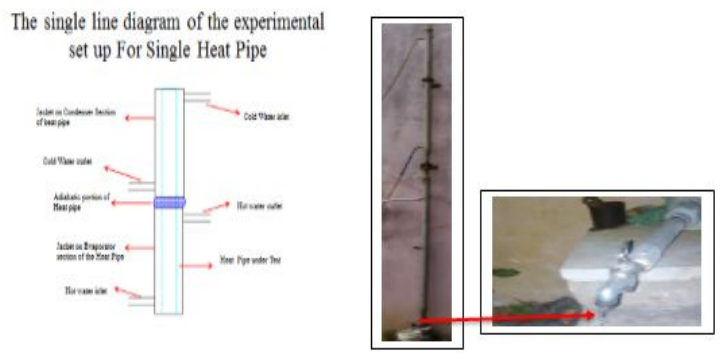

Fig 8.0 Experimental set up with single Heat pipe

The inlet and out let temperatures are measured with the digital thermometers at the inlet and outlet openings. The boiler is operated with $33 \mathrm{~kW}$ heaters. After reaching the steady state conditions, the readings were taken and the performance of heat pipe shown in the Fig 9 


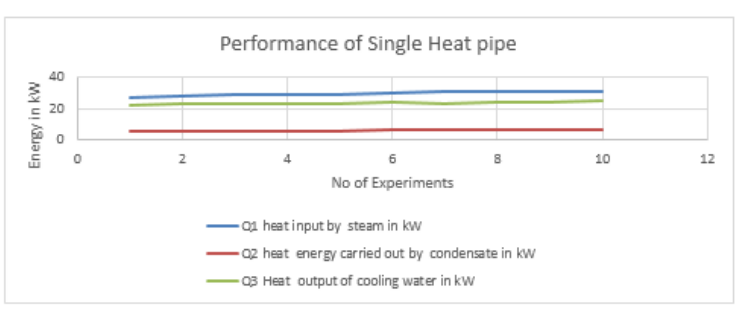

Fig 9 Performance of Single heat pipe

After successful experiments with single heat pipe, the steam condensation with heat pipe based condenser was tried.

Heat pipes based condenser with the above designed heat pipes is fabricated with 16 numbers of heat pipes in the laboratory. The sketch of the experimental set up shown in Fig 10.

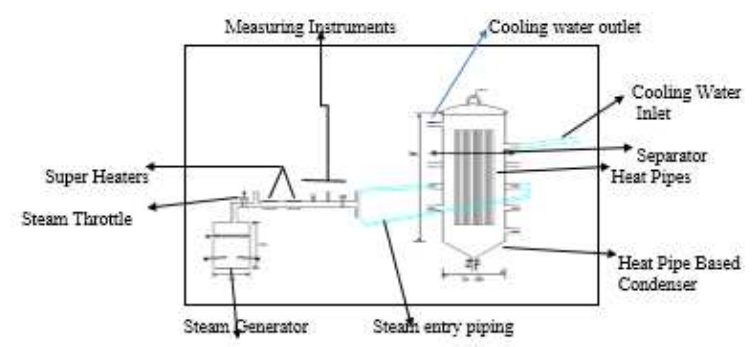

Fig. 10 Line Diagram of Experimental Set up

The heat pipe condenser used for the experiments and experimental set up is shown in Fig 6.3

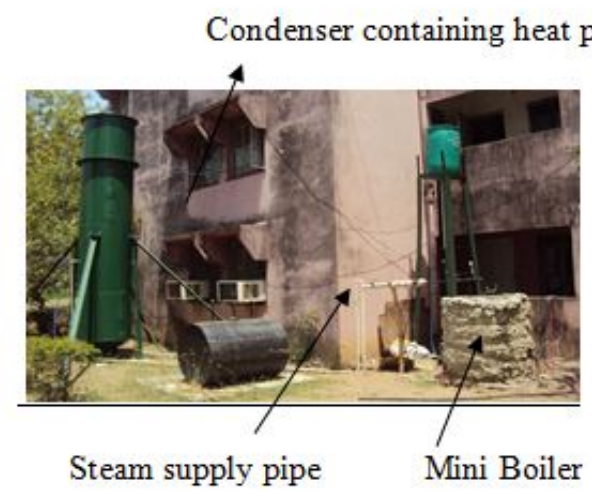

Fig 11 Heat Pipe Heat Exchanger

A miniature steam generator with a heating capacity of $33 \mathrm{~kW}$ made used to supply the steam. The temperature and pressure of the steam measured before throttle valve. The line diagram and experimental set up actual photo are shown in Fig 6.3

\subsection{EXPERIMENTAL RESULTS}

The output of mini boiler and fed into the condenser built by heat pipes. The heat pipe based condenser converts the fed steam into condensate and the resulting condensate flowing outside shown in Fig 12

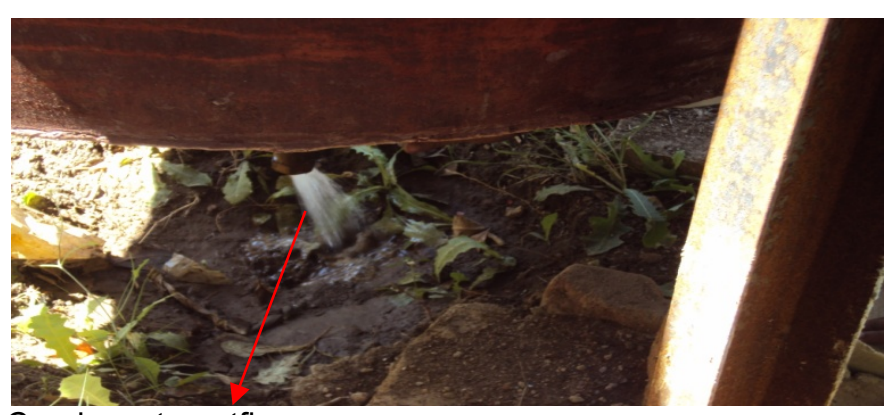

Condensate outflow

Figure. 12 : Flow of Condensate

It is hereby concluded that the heat pipe based condenser is capable of converting the steam into condensate. The outflow of condensate from the tank clearly indicates that the heat pipes are converting the steam continuously. Hence it can concluded that the heat pipes placed inside the condenser are capable of converting steam into the water.

\section{2 \\ Performance of Heat Pipe based Con-} denser

After reaching the steady state conditions, the readings were taken and presented in Table The performance of the heat pipe based condenser experiments cane be represented in the following graph.

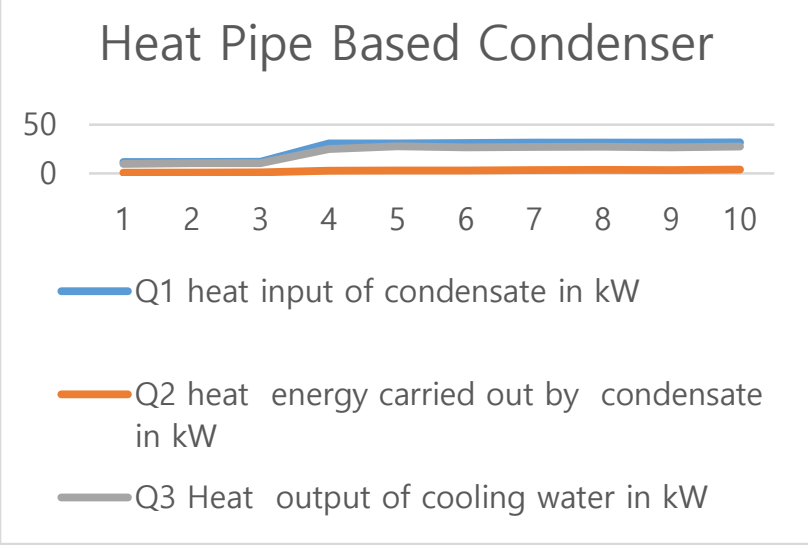


8.0 The comparison between conventional and heat pipe based condenser is tabulated and presented in the Table 7

\begin{tabular}{c|c|c|c}
$\mathrm{S}$ & Parameters & $\begin{array}{c}\text { Table 7 } \\
\text { Conventional } \\
\text { I. }\end{array}$ & $\begin{array}{c}\text { Heat pipe } \\
\mathrm{N}\end{array}$ \\
$\mathrm{o}$ & & $\begin{array}{c}\text { Condenser } \\
\text { based con- } \\
\text { denser }\end{array}$ & \\
\hline 1 & Effectiveness & $55 \%$ & $0.99 \%$ \\
\hline 2 & $\begin{array}{c}\text { Heat transfer } \\
\text { rate }\end{array}$ & $15 \mathrm{~kW} / \mathrm{m}^{2}$ & $85 \mathrm{~kW} / \mathrm{m}^{2}$ \\
\hline 3 & $\Delta$ Eex $=$ Quan- & $11,761 \mathrm{~kW}$ & $5963 \mathrm{~kW}$
\end{tabular}

\section{NOMENCLATURE}

\section{English}

A cross sectional area, $\mathrm{m}^{2}$

C Heat Capacity

c Specific heat

d diameter, $m$

$\mathrm{g}$ gravitational acceleration, $\mathrm{m} \cdot \mathrm{s}^{-2}$

$\mathrm{H}$ height, $\mathrm{m}$

$\mathrm{n}$ total number of tubes

$\mathrm{L}$ length, $\mathrm{m}$

$\mathrm{m}$ mass flow rate, $\mathrm{kg} / \mathrm{s}$

$\mathrm{P}_{\text {atm }}$ atmosphere pressure, $\mathrm{N} . \mathrm{m}^{-2}$,

Psys system pressure, N. $\mathrm{m}^{-2}$

$Q \quad$ Steam Load

$r$ radius, $m$

S Specific heat

h Heat transfer coefficient

$\mathrm{t} \quad$ thickness in $\mathrm{m}$

$\mathrm{T} \quad$ Temperature

CW Cooling water quantity

R Thermal Resistance

\section{References}

[1]. Heat Pipes, Second Edition, P.Dunn and D.A. Reay , Pergamon Press

[2]. Amir Faghri "Heat Pipe Science and Technology" Taylor and Francis, Washngton Dc, USA, 1995

[3]. Heat Pipe Waste Heat Recovery by D.A. Littwin,J.M.C. Curley , Journal of Heat Recovery System, Elseveir Vol 1, Issue 4,1981, Page : 339-348

[4]. Vasiliev L.L., Grakovich P., Khrustalev D.K., Kiselev V.G., Matveev Yu. (1984) $\underline{\text { Heat }}$
4

\begin{tabular}{c|c|c} 
Operating and & $\begin{array}{c}19,200 \text { tubes } \\
\text { are to be } \\
\text { handled }\end{array}$ & $\begin{array}{c}9025 \text { tubes } \\
\text { are to han- } \\
\text { dled }\end{array}$
\end{tabular}

\subsection{CONCLUSIONS}

Heat pipes can be used for steam condensation purpose and may be replaced with the conventional nonferrous tubes used in the conventional condenser. Use of the heat pipes in place of conventional condenser increase the effectiveness of condenser as well as reduces the size of condenser and also exergy destruction can be reduced.

\subsection{ACKNOWLEGGEMENT}

The author expresses his gratitude to M/s. Central Power Research Institute for funding the project and accord permisson to publish this technical paper. pipes and heat pipe exchangers for heat recovery systems, Journal of Heat Recovery Systems, Vol. 4, Iss. 4, pp. 227-233.

[5]. Research, Development and Industrical Application of Heat Pipe Technology in China, Hong Z Hang, Jun Zhuang , Applied Theraml Engineering , 2003 ,23,9,Pg 10671083

[6]. Review " Heat Pipes in modern Heat Exchangers, Leonard L. Vasiliev, Applied Terhmal Engineering 25 (2005) 1-19

[7]. Retrofitting of power plant condensers with heat pipe heat exchanger: A case STUDY by T.Mallikharjuna Rao and S.S.Rao VIII Minsk International Seminar "Heat Pipes, Heat Pumps, Refrigerators, Power Sources", Minsk, Belarus, September 12-15, 2011

[8]. Azad,E, " A design procedure for gravity assisted heat pipe heat exchanger, Journal of heat recovery system, 1984

[9]. Compact Heat Exchangers by Kays and London, Mc Graw Hill Book Company

[10] Analysis of Exergy Destruction of an Evaporator or/and a Condenser" Published in Strojarstvo 51 (1) 73- 782000 , ISSN 056201887 - Antun Galovic, Marija Zivic and Mato Kokanovic

[11] Investigation of Thermal performance of an air to air thermosyphon heat ex changer using $\varepsilon$ - NTU method By S.H Noie, Elsevier, Applied Ther mal Engineering 26(2006) 


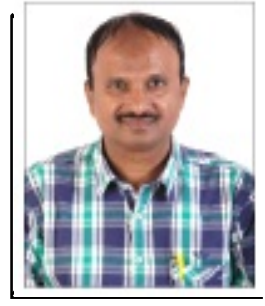

Mallikharjuna Rao Tarla, a post graduate in M.Tech ( $T$ hermal Eng) from JNTU, Hy derabad is serving at Centr al Power Research Institute since 20 years. He is having expertise in Remaining life es timation studies, Non-destructi ve evaluation,condition assessment, thermal ma pping and internal inspection of plant componen ts, Energy audits, Insulation Audits in the power plants and Studies of Heat Pipes for better he at transfer devices. He is an accredited Energy Auditor. He has more than 20 national and inte rnational publications. 
Figures

Figure 1

Figure 1 is not available in this version 


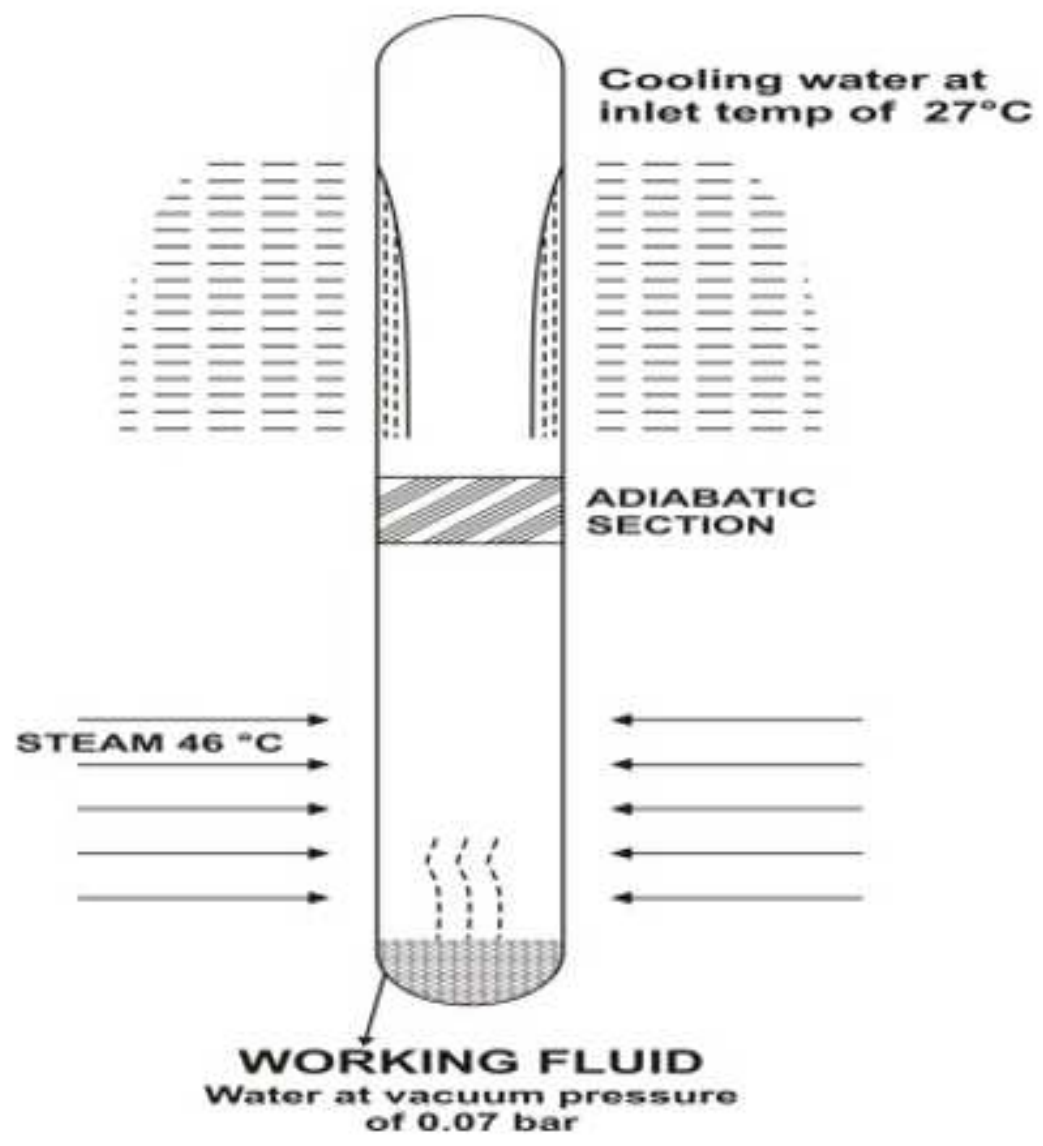

Figure 2

Proposed concept steam condensation
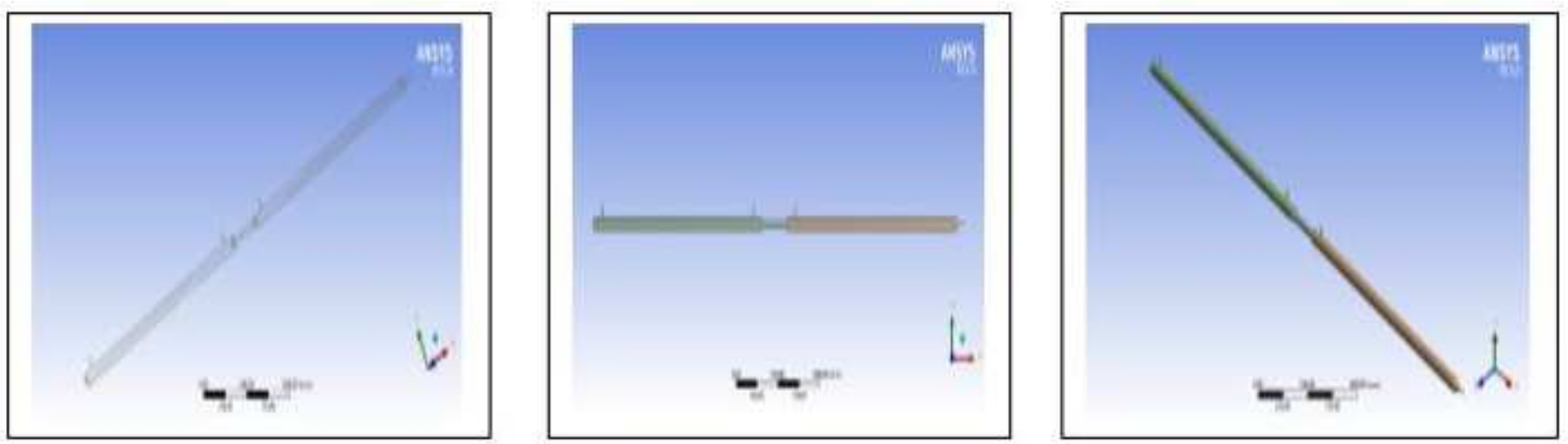

Figure 3

The Heat pipes under analysis. 

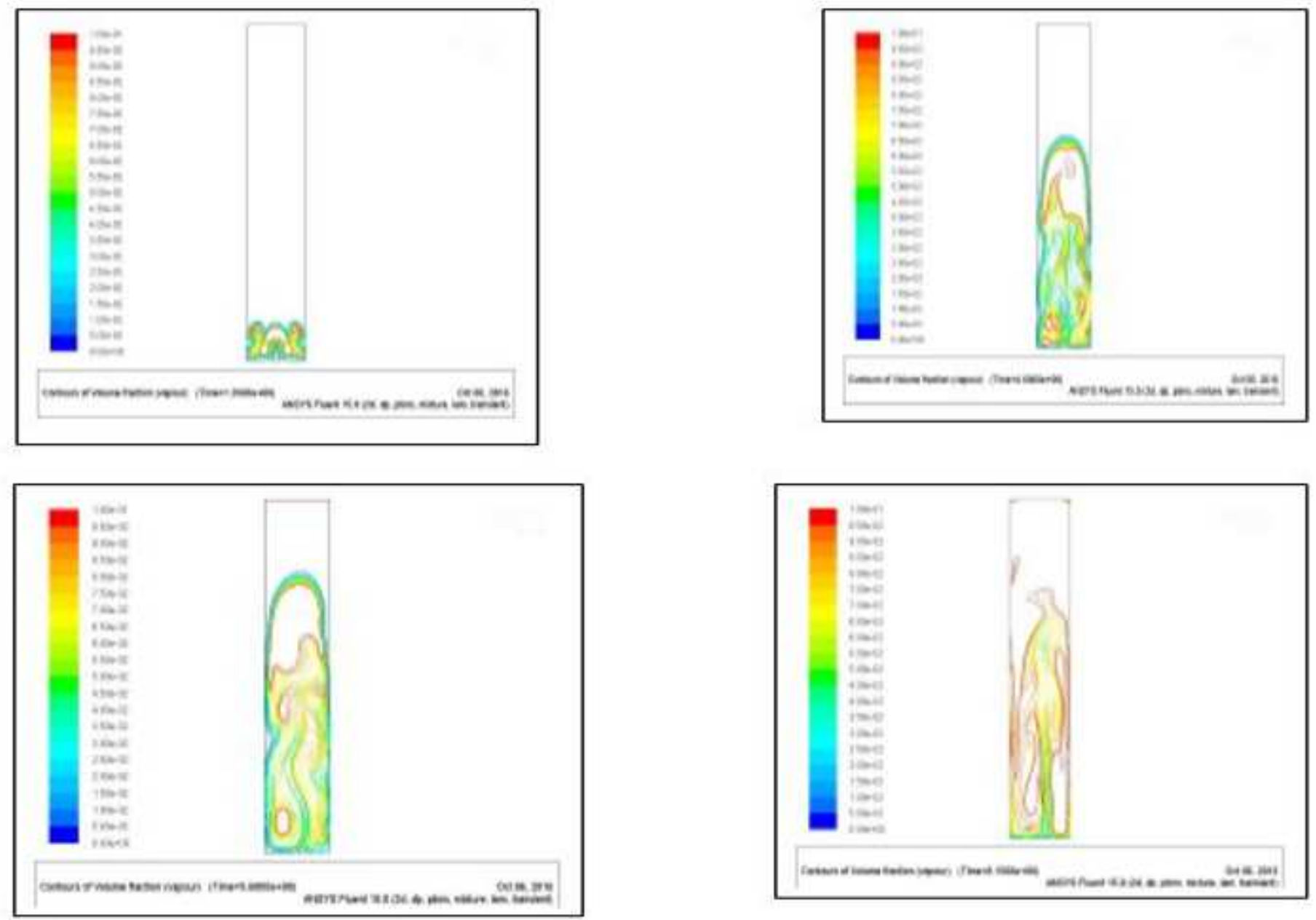

Figure 4

Heat pipe liquid changes inside heat pipe

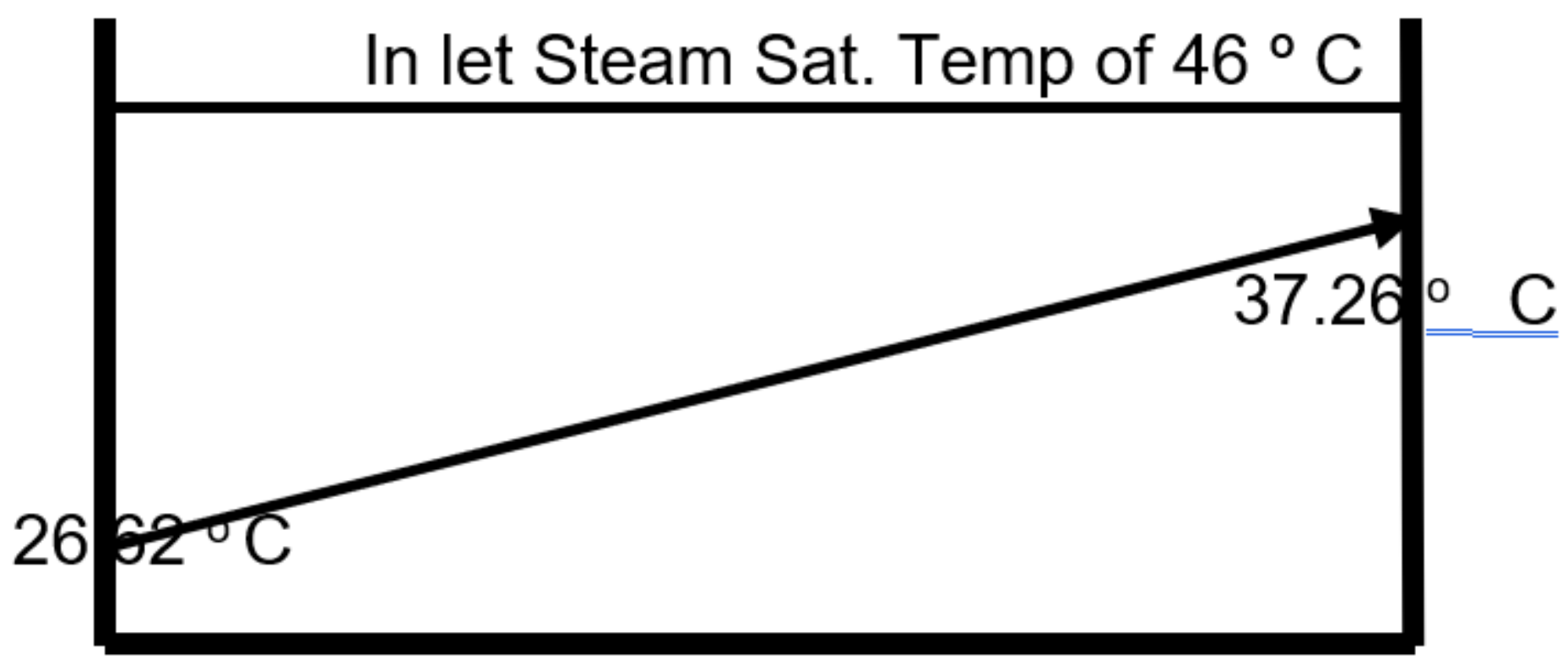

Figure 5 


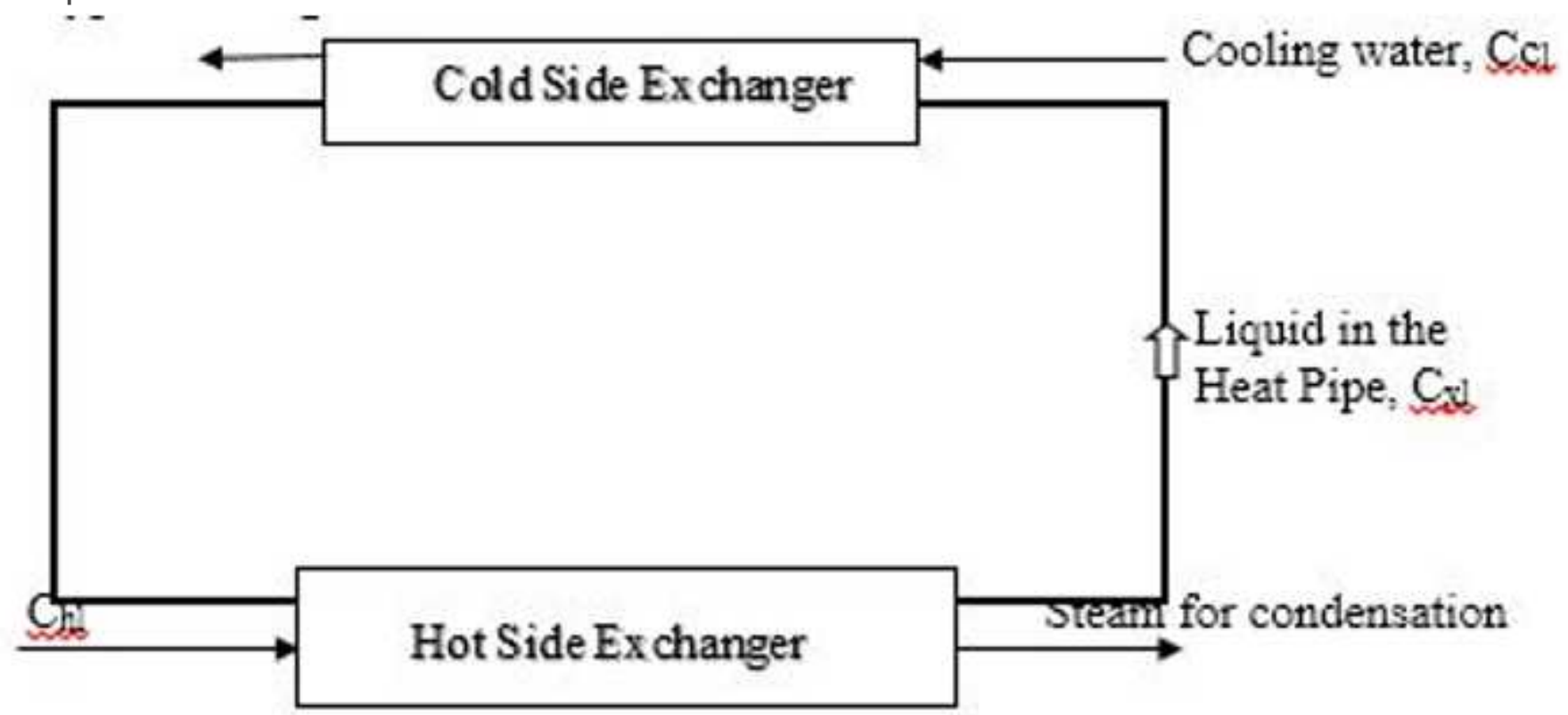

Figure 6

Equivalence between HP condenser and liquid coupled indirect Heat Exchanger

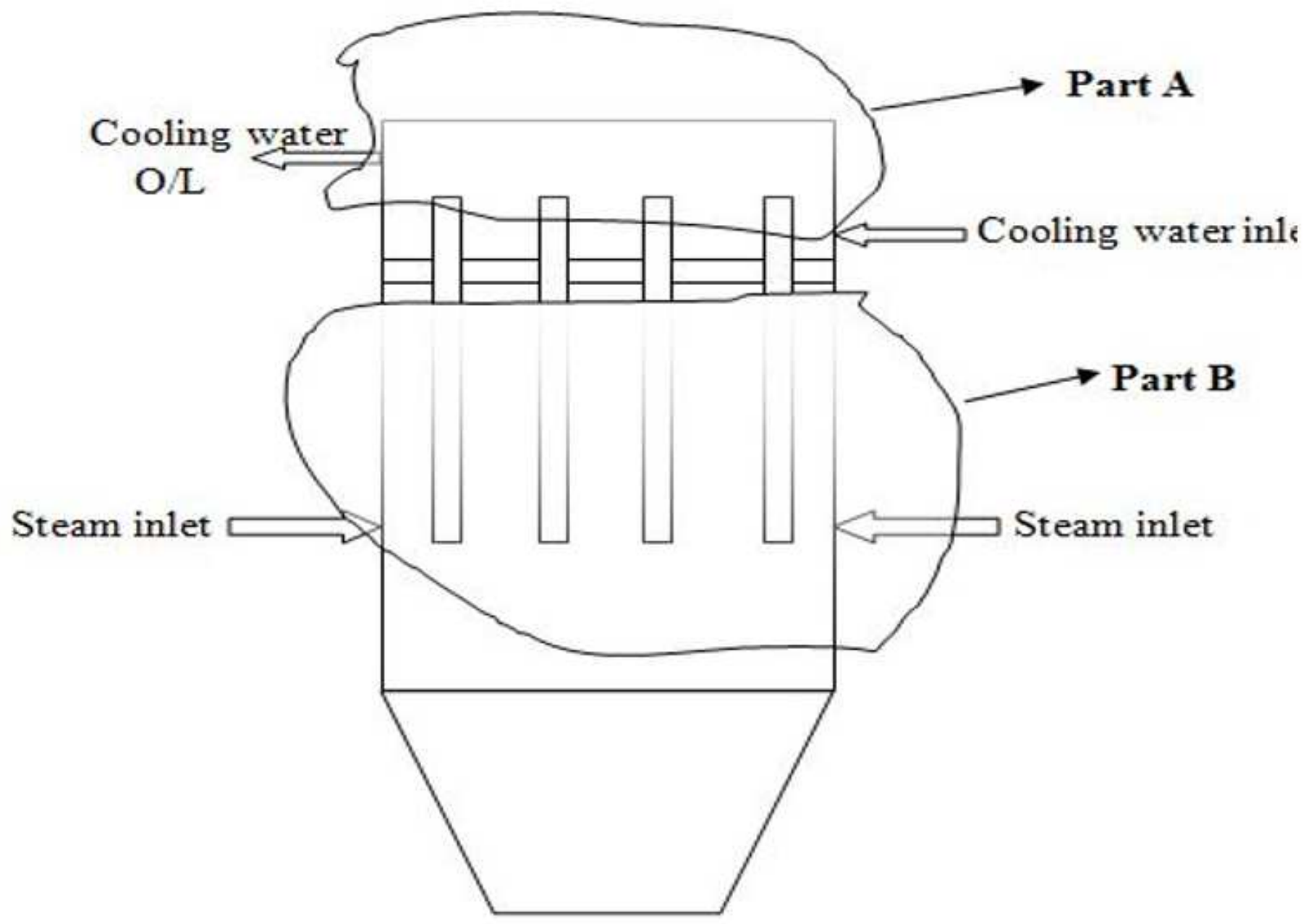


Figure 7

Exergy Analysis

The single line diagram of the experimental set up For Single Heat Pipe
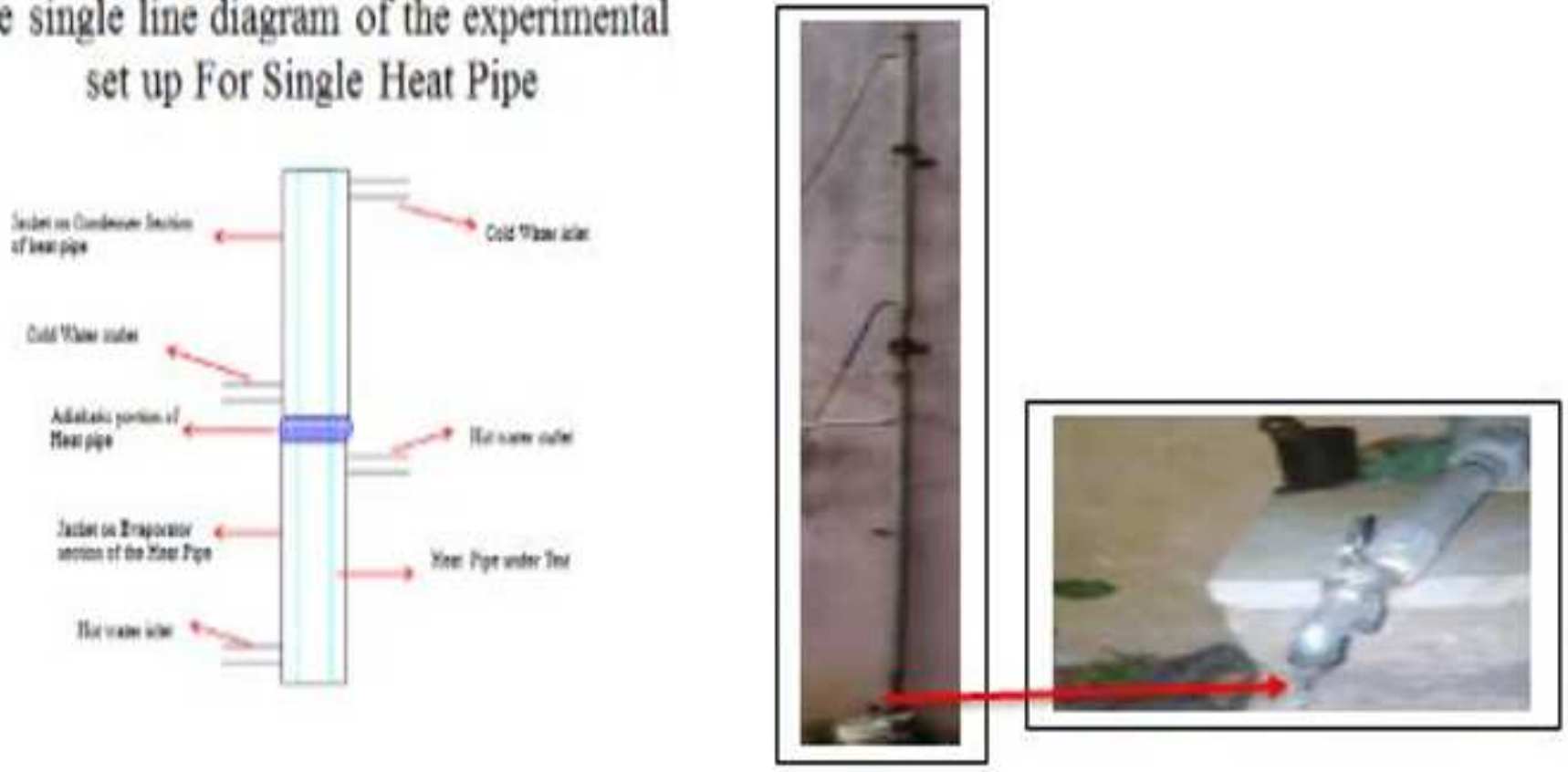

\section{Figure 8}

Experimental set up with single Heat pipe

\section{Performance of Single Heat pipe}

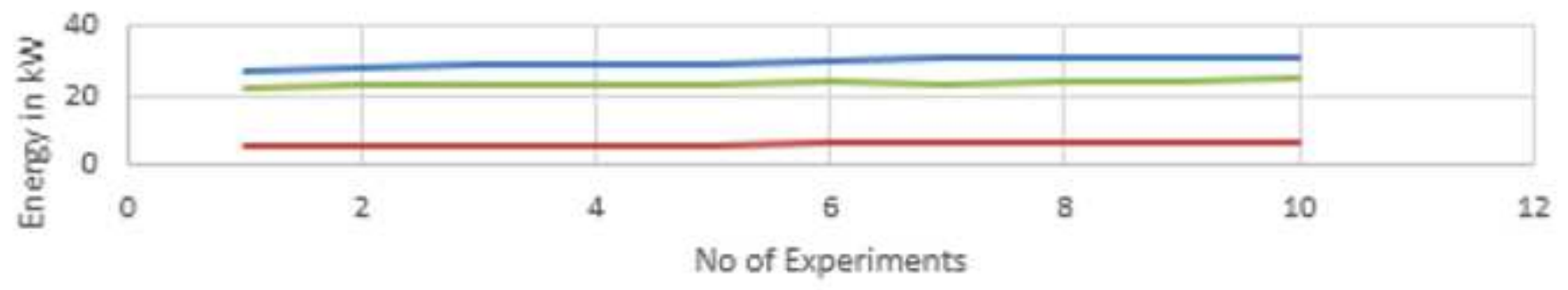

- 02 heat input by steam in $\mathrm{kW}$

- 22 heat energy carried out by condensate in KW

- Q3 Heat output of cooling water in kW

\section{Figure 9}

Performance of Single heat pipe 


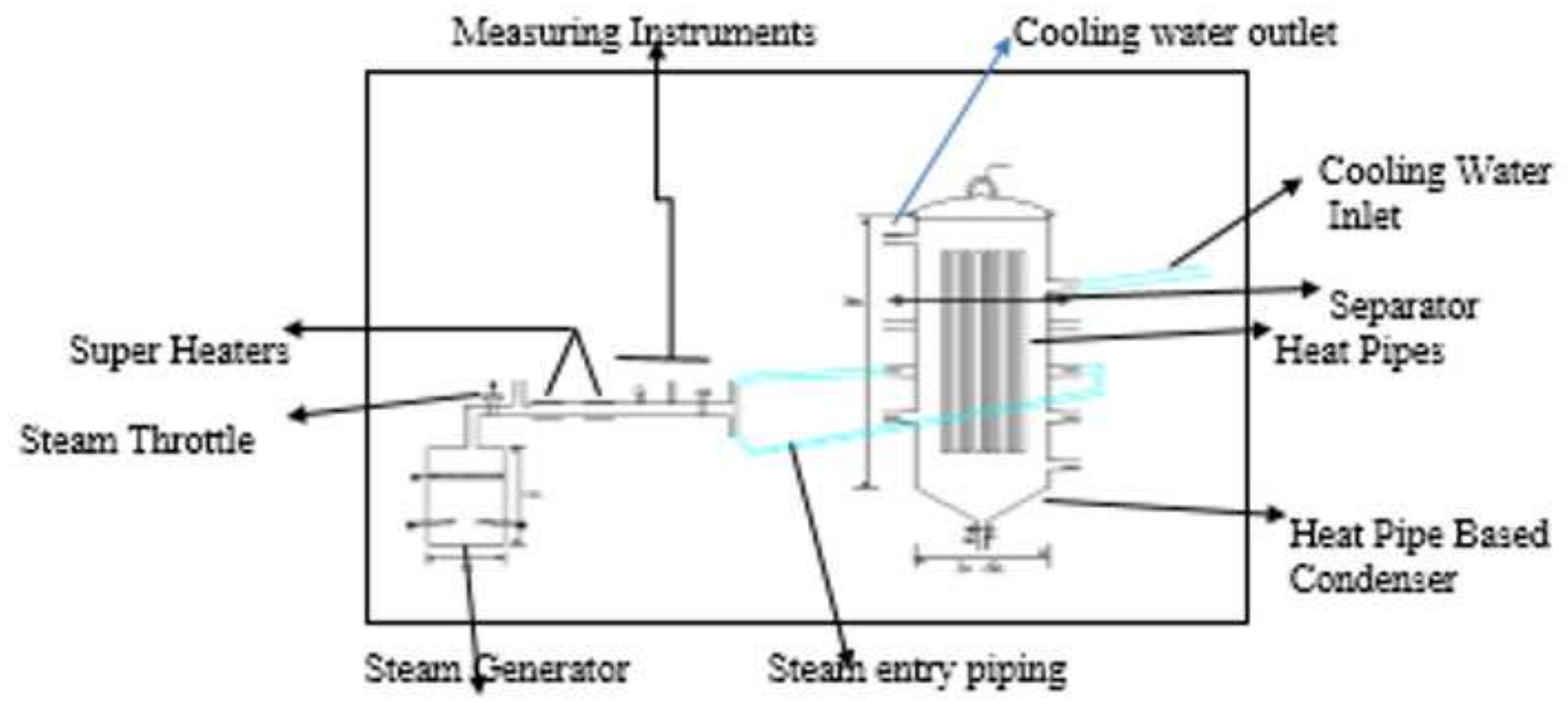

Figure 10

Line Diagram of Experimental Set up

\section{Condenser containing heat $\mathrm{F}$}

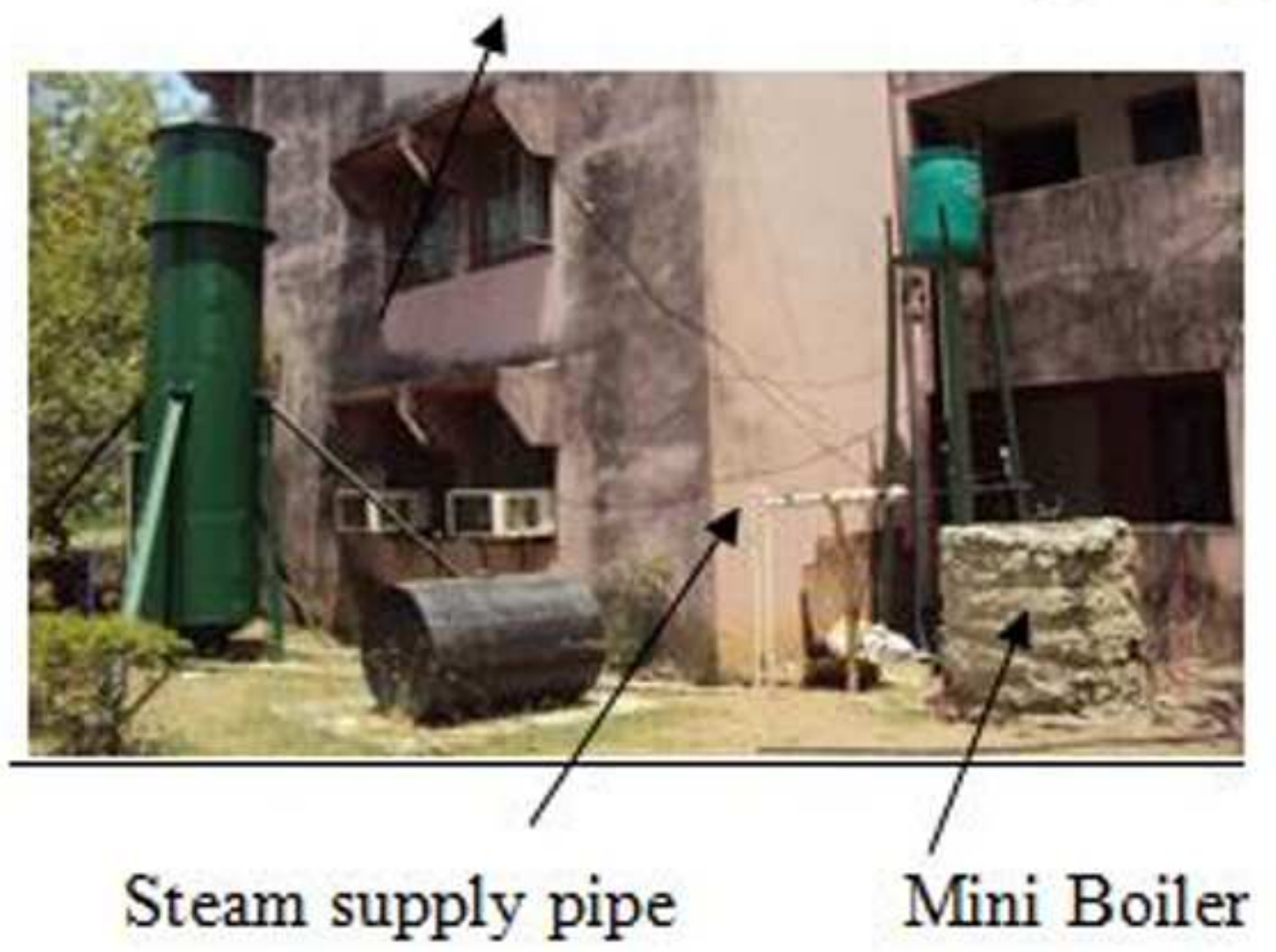




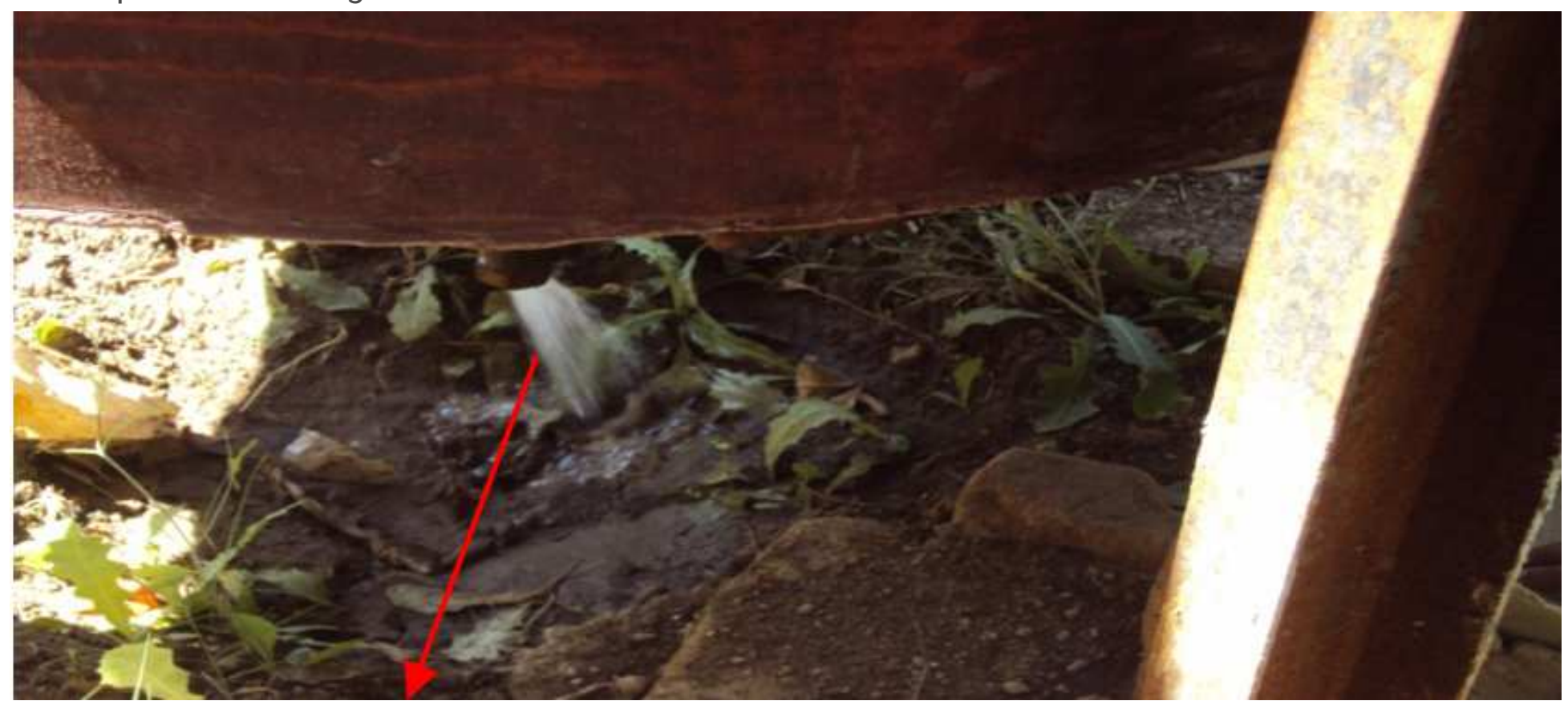

Figure 12

Flow of Condensate 